\title{
Comparative analyses of putative toxin gene homologs from an Old World viper, Daboia russelii
}

\author{
Neeraja M Krishnan ${ }^{1}$, Binay Panda ${ }^{\text {Corresp. } 1}$ \\ ${ }^{1}$ Ganit Labs, Bio-IT Centre, Institute of Bioinformatics and Applied Biotechnology, Bangalore, India \\ Corresponding Author: Binay Panda \\ Email address: binay@ganitlabs.in
}

Availability of snake genome sequences has opened up exciting areas of research on comparative genomics and gene diversity. One of the challenges in studying snake genomes is the acquisition of biological material from live animals, especially from the venomous ones, making the process cumbersome and time-consuming. Here, we report comparative sequence analyses of putative toxin gene homologs from Russell's viper (Daboia russelii) using whole-genome sequencing data obtained from shed skin. When compared with the major venom proteins in Russell's viper studied previously, we found 45-100\% sequence similarity between the venom proteins and their putative homologs in the skin. Additionally, comparative analyses of 20 putative toxin gene family homologs provided evidence of unique sequence motifs in nerve growth factor (NGF), platelet derived growth factor (PDGF), Kunitz/Bovine pancreatic trypsin inhibitor (Kunitz BPTI), cysteine-rich secretory proteins, antigen 5, andpathogenesis-related 1 proteins (CAP) and cysteine-rich secretory protein (CRISP). In those derived proteins, we identified V11 and T35 in the NGF domain; F23 and A29 in the PDGF domain; N69, K2 and A5 in the CAP domain; and Q17 in the CRISP domain to be responsible for differences in the largest pockets across the protein domain structures in crotalines, viperines and elapids from the in silico structurebased analysis. Similarly, residues F10, Y11 and E20 appear to play an important role in the protein structures across thekunitzprotein domain of viperids and elapids. Our study highlights the usefulness of shed skin in obtaining good quality high-molecular weight DNA for comparative genomic studies, and provides evidence towards the unique features and evolution of putative venom gene homologs in vipers.

Data deposition: Russell's viper sequence data is deposited in the NCBI SRA database under the accession number SRR5506741 and the individual gene sequences are deposited in the GenBank (accession numbers in Table S1). 
1 Comparative analyses of putative toxin gene homologs from an Old World viper,

2 Daboia russelii

3 Neeraja M Krishnan ${ }^{1}$ and Binay Panda ${ }^{1 *}$

$4{ }^{1}$ Ganit Labs, Bio-IT Centre, Institute of Bioinformatics and Applied Biotechnology,

5 Biotech Park, Electronic City Phase I, Bangalore 560100

6 * Corresponding author: binay@ganitlabs.in 


\section{Abstract}

Availability of snake genome sequences has opened up exciting areas of

9 research on comparative genomics and gene diversity. One of the challenges in

10 studying snake genomes is the acquisition of biological material from live animals,

11 especially from the venomous ones, making the process cumbersome and time-

12 consuming. Here, we report comparative sequence analyses of putative toxin gene

13 homologs from Russell's viper (Daboia russelii) using whole-genome sequencing data

14 obtained from shed skin. When compared with the major venom proteins in Russell's

15 viper studied previously, we found $45-100 \%$ sequence similarity between the venom

16 proteins and their putative homologs in the skin. Additionally, comparative analyses of 20

17 putative toxin gene family homologs provided evidence of unique sequence motifs in

18 nerve growth factor (NGF), platelet derived growth factor (PDGF), Kunitz/Bovine

19 pancreatic trypsin inhibitor (Kunitz BPTI), cysteine-rich secretory proteins, antigen 5,

20 and pathogenesis-related 1 proteins (CAP) and cysteine-rich secretory protein (CRISP).

21 In those derived proteins, we identified V11 and T35 in the NGF domain; F23 and A29 in

22 the PDGF domain; N69, K2 and A5 in the CAP domain; and Q17 in the CRISP domain

23 to be responsible for differences in the largest pockets across the protein domain

24 structures in crotalines, viperines and elapids from the in silico structure-based analysis.

25 Similarly, residues F10, Y11 and E20 appear to play an important role in the protein

26 structures across the kunitz protein domain of viperids and elapids. Our study highlights

27 the usefulness of shed skin in obtaining good quality high-molecular weight DNA for

28 comparative genomic studies, and provides evidence towards the unique features and

29 evolution of putative venom gene homologs in vipers. 
30 Data deposition: Russell's viper sequence data is deposited in the NCBI SRA database

31 under the accession number SRR5506741 and the individual gene sequences are

32 deposited in the GenBank (accession numbers in Table S1). 
33 Introduction

34 Snake venom genes and their products offer an excellent model system to study

35 gene duplication, evolution of regulatory DNA sequences, and biochemical diversity and

36 novelty of venom proteins. Additionally, snake venoms have tremendous potential in the

37 development of new drugs and bioactive compounds (Vonk et al. 2011). Previous

38 studies have highlighted the importance of gene duplications and/or sub-

39 functionalization (Hargreaves et al. 2014; Malhotra et al. 2015; Rokyta et al. 2011) and

40 transcriptional/post-transcriptional mechanisms (Casewell et al. 2014) contributing

41 towards snake venom diversity. Venom studies, so far, have extensively used data from

42 proteomics experiments alongside individual gene sequences or sequences of particular

43 family members to study variations on gene structure and their sequence composition.

44 Presently, whole genome sequences of several snake species, king cobra Ophiophagus

45 hannah (Vonk et al. 2013); Burmese python Python bivitattus (Castoe et al.

46 2013); rattlesnake Crotalus atrox (Dowell et al. 2016); Florida pygmy

47 rattlesnake Sistrurus miliarius barbouri (Vicoso et al. 2013); garter

48 snake Thamnophis elegans (Vicoso et al. 2013); five-pacer

49 viper Deinagkistrodon acutus (Yin et al. 2016); pit viper Protobothops mucrosquamatus

50 (NCBI Accession PRJDB4386); and corn snake Pantherophis guttatus (Ullate-Agote et

51 al. 2014), have either been published or their sequence been made available in the

52 public domain. In addition, genome sequencing efforts are either underway or the

53 sequences of venom-associated genes have been deposited in the databases for a few

54 others (Kerkkamp et al. 2016). Out of the sequenced genomes, only a few have been

55 annotated, or made public, a key requirement for comparative analysis of genes. This,

56 along with the lack of availability of whole genome sequences and/or complete transcript 
57 sequences from venom glands for most snakes has limited studies on toxin

58 gene orthologies and gene variation among venomous snakes.

59 Four snakes, Russell's viper (Daboia russelii), saw-scaled viper (Echis carinatus),

60 spectacled cobra (Naja naja), and common krait (Bungarus caeruleus) are responsible

61 for most snakebite-related mortality in India (Mohapatra et al. 2011; Warrell et al. 2013;

62 Whitaker 2015). Russell's viper is a member of the taxon Viperidae and subfamily

63 Viperinae and is responsible for large numbers of snakebite incidents and deaths in

64 India. Very little is known about the diversity of genes from any viper, including the only

65 viperine where complete genome sequence information is available (European

66 adder, Vipera berus berus, https://www.ncbi.nlm.nih.gov/bioproject/170536). Lack of

67 gene annotation from this viper using transcripts obtained from venom glands and other

68 snake species reduces the scope of a detailed comparative study on genes, including

69 the toxin-associated genes. Such a study involving various groups of venomous and

70 non-venomous snakes, in addition to other venomous vertebrates and invertebrates, will

71 facilitate our understanding on the evolution of these genes, their diversity, and function.

72 One of the challenges in studying the genomes of venomous animals is related to

73 sample acquisition. Additionally, in India, Government permission is required to catch

74 snakes and extract blood samples from them (all snakes are protected in India under the

75 Indian Wildlife Protection Act, 1972). This may be partially circumvented by the use of

76 shed skin that does not require drawing blood or taking any tissue from the animals.

77 However, working with DNA isolated from shed skin has its own challenges. Microbial

78 contamination, lack of full-length DNA in the shed skin cells, rapid degradation of DNA in

79 humid conditions and computational challenges in dealing with short stretches of DNA

80 are some of the bottlenecks for working with DNA from shed skin. 
81 In the current study, we explored the possibility of getting putative toxin gene

82 homolog information from skin-derived low-coverage whole-genome sequencing data

83 from Russell's viper, and performed comparative analysis versus major toxin proteins

84 from a previously studied report (Sharma et al. 2015). We used the coding sequences

85 and annotation from a previously characterized crotaline, a pit

86 viper, Protobothrops mucrosquamatus for the analysis. On the venom homologs, we

87 focused our analyses on five key protein domains; nerve growth factor (NGF), platelet

88 derived growth factor (PDGF), Kunitz/Bovine pancreatic trypsin inhibitor (Kunitz BPTI),

89 cysteine-rich secretory proteins, antigen 5 , and pathogenesis-related 1 proteins (CAP)

90 and cysteine-rich secretory protein (CRISP) in Russell's viper. Our study identified the

91 putative venom homologs from skin and the key residues that are changed across the

92 members of Viperinae, Crotalinae and Elapidae that might have contributed towards the

93 evolution of venom in vipers.

\section{Materials and Methods}

95 Russell's viper shed skin and DNA isolation

96 Freshly shed skin of Russell's viper from Bangalore, India was a gift from Mr.

97 Gerry Martin. The shed skin for the entire snake was obtained, cleaned thoroughly with

$9870 \%$ ethanol and with nuclease-free water 3 times each, dried thoroughly and frozen

99 until the time of extraction of DNA. Genomic DNA was extracted following the protocol of

100 Fetzner (Fetzner 1999) with modifications.

101 Sequencing, read processing and assembly

102 Illumina paired-end read libraries (100 base paired-end reads with insert size of

103350 bases) were prepared following the manufacturer instructions using amplification

104 free genomic DNA library preparation kit and sequenced using Illumina HiSeq2500

105 instrument. Archaeal, bacterial and human sequence contamination were removed 
106 from the Russell's viper sequence by DeConSeq (Schmieder \& Edwards 2011) using

107 curated and representative

108 genomes (https://www.ncbi.nlm.nih.gov/genome/browse/reference/).

109 Furthermore, the sequenced reads were post-processed to remove unpaired reads and

110 quality analysis was performed using FastQC v0.1

111 (http://www.bioinformatics.babraham.ac.uk/projects/fastqc/). The rd_len_cutoff option

112 was exercised during the read assembly step to trim off the low-quality bases, since the

113 per-base quality was found to drop below 28 after the initial 50-70 bases of the read.

114 The Russell's viper read libraries with 26X coverage were assembled using

115 SOAPdenovo2 (r240) (Luo et al. 2012).

116 Identifying toxin gene homologs, coding regions, and predicted gene structures

117 The DNA sequences for 51 out of 54 venom-associated genes (Fry 2005)

118 from Protobothrops mucrosquamatus were downloaded (Table 1). These were used to

119 fish genomic scaffolds bearing highly similar sequences in Russell's viper genome

120 assembly, using BLAST with an E-value threshold of $10^{-3}$. The fished scaffolds were

121 then anchored to the respective coding sequences

122 from Protobothrops mucrosquamatus, using a discontiguous megaBlast, to determine

123 the correct frame of translation and extract the complete amino acid coding sequence

124 (CDS) corresponding to putative toxin homologs in Russell's viper. We obtained the

125 exon-intron structures for all the putative toxin gene homologs in Russell's viper by

126 aligning the CDS with gene sequences using discontiguous megaBlast and plotted using

127 the tool GSDS2.0 (Hu et al. 2015). The sequences for the Russell's viper putative

128 venom gene homologs were deposited in GenBank and their accession numbers are

129 provided in Table S1.

130 Comparative analysis between venom proteins and their putative homologs 
We obtained the accession IDs for the major toxin families from Russell's viper of

132 the Indian sub-continent (Supplementary Figure S1 in Sharma et al. 2015). Their

133 corresponding protein sequences were matched using blastp with the amino acid

134 sequences from the putative skin homologs. For the genes covered under each family, a

135 percent identity metric, indicative of the extent of sequence similarity between the

136 venom proteins and their skin homologs, was estimated. Similar comparative analyses

137 were performed for king cobra (Ophiophagus hannah) using accession IDs provided in

138 Additional File 4 of Tan et al. 2015, and the predicted toxin protein homologs from blood

139 of king cobra (PRJNA201683 from Vonk et al. 2013). Comparative analyses were

140 performed using blastp, with the venom protein sequence as the query, against

141 PRJNA201683.

142 Comparative analyses of putative venom protein homolog domains

143 The amino acid sequences of all the Russell's viper's putative toxin homologs

144 were subjected to domain search using Pfam (Finn et al. 2016) (Table S2). All domain

145 sequences were aligned using blastp to non-redundant protein sequences from 18

146 snake species (Table S3). We wanted to compare the gene structures between the

147 venomous and the non-venomous animals, hence included sequence information from

148 the members of the later group. Five domains (NGF, PDGF, Kunitz BPTI, CAP and

149 CRISP) from four genes (NGF, VEGF, CRISP/Serotriflin, and Kunitoxin) with variability

150 across different snake groups were used for expansive comparative analyses (Table

151 S4). The sequences used were from viperids (taxid: 8689), elapids (taxid: 8602),

152 colubrids (taxid: 8578), boids (taxid: 8572), acrochordids (taxid: 42164), pythonids (taxid:

153 34894), lizards (squamates (taxid: 8509) minus snakes (taxid: 8570)), crocodiles (taxid:

154 51964) and testudines (taxid: 8459).

$1553 D$ structure prediction of the chosen domains 
157 CRISP domain alignments using Simple Consensus Maker

158 (https://www.hiv.lanl.gov/content/sequence/CONSENSUS/SimpCon.html) for crotalines

159 (CR), viperines (VP) and elapids. The consensus sequences were submitted to the

160 protein fold recognition server (Kelley et al. 2015) using standard mode

161 (http://www.sbg.bio.ic.ac.uk/phyre2/html/page.cgi?id=index). The best 3D model was

162 further investigated by Phyre2 to analyze the structural model using various open source 163 tools.

\section{Results}

165 Shed skin yielded fairly good quality and high-molecular weight genomic DNA

166 Genomic DNA isolated from the shed skin of Russell's viper was fairly intact with

167 most of the DNA in the size range of more than $5 \mathrm{kbp}$ (Fig. S1). Sequenced short reads

168 were assembled and then used to fish the sequences for the 51 putative toxin genes in

169 Russell's viper (see Materials and Methods). Next, we obtained the exon-intron

170 structures for all putative homologs in Russell's viper by aligning the CDS with gene

171 sequences (Fig. S2). We found the average length of the exons in those sequences to

172 be around 190 nucleotides (nt), matching well with the lengths of other vertebrate exons

173 (Gelfman et al. 2012).

174 Similarity between venom proteins and their putative skin homologs

175 For the Russell's viper, we found 45 - 100\% sequence similarity between the

176 major venom proteins and their predicted putative skin homologs (Figure 1). The

177 sequences for venom nerve growth factor (VNGF) and its putative skin homolog were

178 identical. Similarly, VEGF and CRISPs from venom gland were highly similar to their

179 putative skin homologs (99\% and $92 \%$ sequence similarity respectively). Other proteins

180 like, KSPI, SVSPs and PLA2 showed $79 \%, 74 \%$ and $61 \%$ sequence identity, 
181 respectively (Figure 1 and Fig. S3). In order to find out whether the sequence

182 divergence between some of the venom gland proteins and their predicted putative skin

183 homologs was specific to Russell's viper, we performed similar analysis using venom

184 proteins and their blood homologs from king cobra, Ophiophagus hannah (Vonk et al.,

185 2013). In the case of Ophiophagus hannah, the differences between toxin proteins and

186 their blood homologs were minor for most families studied (similarity $>=75 \%$ ), except for

187 PLA2, which had a low similarity of 23\% (Fig. S4 and Fig. S5).

188 Comparative domain analyses

189 Among the genes, a larger pool of sequences were available only for NGF, PDGF

190 domain of VEGF, Kunitz_BPTI domain of Kunitoxin, CRISP and CAP domains in CRISP

191 and Serotriflin proteins, from various snake groups (Colubridae, Boidae, Pythonidae and

192 Acrochordidae), non-snake reptilian groups (lizards, crocodiles and Testudines),

193 venomous invertebrates (wasps, spiders and scorpions) and venomous vertebrates

194 (fishes and mammals). Therefore, these domains were compared with their putative

195 homologs from Russell's viper. Comparative domain analysis was performed for all

196 putative toxin gene homologs (Fig. S6) across 18 snake species for those where

197 sequence information was available (Table S3). In the case of five domains: CAP and

198 CRISP domains of CRISP and serotriflin genes ( $L$ and $A L)$, Kunitz BPTI of kunitoxin (S),

199 NGF (T) and PDGF of VEGFA (AP-AR) and VEGFF (AU), we found that the maximum

200 number of species aligned to their domain sequences. Some protein domains, the

201 CRISP, Kunitz BPTI, guanylate CYC, PDGF of VEGFF and WAP, showed long stretches

202 of mismatches (Fig. S6) compared with Russell's viper sequence. Out of these, only

203 NGF and PDGF domains of VEGF had amino acid changes specific to the members of

204 the group Crotalinae, that were completely absent in any other group used for 
205 comparison, including in lizards, crocodiles, and turtles (Fig. S7). Specific changes in 206 these proteins and their implications are discussed below.

207 The putative skin-derived NGF gene homolog in Russell's viper is a single exon 208 gene with a $745 \mathrm{nt}$ transcript coding for a 244 amino acid protein consisting of a single 209 NGF domain (Figure 2A). The NGF domain bears $28 \%$ sequence conservation across 210 all the five vertebrate phyla, namely, fishes, amphibians, reptiles, aves and mammals

211 distributed along the length of the domain (Figure 2B). Thirty-six percent out of these 212 residues are conserved across other venomous vertebrates (fishes, squamates and 213 mammals) and venomous invertebrates (scorpions and wasps) (Figure 2C). Thirteen 214 percent of the skin-derived putative NGF domain residues are variable with respect to 215 the domain sequence in at least one among the NGF sequences in the groups of 216 viperids and elapids (Figure 2D). Although several amino acids in the NGF domain in 217 crotalines seem to have changed from the putative domain in Russell's viper and other 218 vipers of the group Viperinae, their function probably remains unchanged. For example, 219 phenylalanine $(F)$ to isoleucine $(\mathrm{I})$ at position 12 and serine $(\mathrm{S})$ to asparagine $(\mathrm{N})$ at 220 position 19 between the crotalines and viperines does not change the function of the 221 amino acids (from one hydrophobic amino acid to another and from one polar amino 222 acid to another). However, it is also true that $\mathrm{F}$ changing to I removes the bulky aromatic 223 ring, whereas $\mathrm{S}$ could be a phosphorylated site as opposite to the $\mathrm{N}$ in the same 224 position. There are others, for example, threonine $(T)$ and glutamine $(Q)$, at positions 67 225 and 68, respectively, in the NGF domain of the crotalines, which were only there in that 226 specific group. One of those, a polar amino acid glutamine at position 68 , is a very 227 important residue as its corresponding amino acid in any of the other snakes, except in 228 colubrids, is a hydrophobic proline. 
230 exons coding for a 652nt long transcript and a translated protein with two domains:

231 PDGF and VEGF-C (Figure 3A). The PDGF domain sequence exhibits conservation in

$23265 \%$ of its residues across the three vertebrate phyla (reptiles, birds and mammals)

233 (Figure 3B). Since sequence information from fishes and amphibians were not available,

234 we could not include those in the comparison study. Out of the conserved residues in

235 the above said domain, $21 \%$ were also conserved in venomous vertebrates (squamates

236 and mammals) and venomous invertebrates (wasps). Fifteen percent of the PDGF

237 domain residues were variable in at least one of the two snake groups: viperids and

238 elapids (Figure 3C and Figure 3D). Like the NGF domain, the evolution of the putative

239 skin-derived PDGF domain in crotalines at certain amino acids is striking. For example,

240 in the crotalines, the position 67 is a polar amino acid tyrosine $(\mathrm{Y})$ while in all other

241 reptiles, venomous invertebrates and mammals; this is primarily a hydrophobic amino

242 acid phenylalanine (F).

243 The putative skin-derived Kunitoxin gene homolog in Russell's viper is a $3.1 \mathrm{~kb}$

244 gene comprising two exons, with a transcript length of 270 nt that codes for a 44 amino

245 acids long single Kunitz BPTI domain (Figure 4A). About 29\% of the protein domain

246 residues are conserved across the four vertebrate phyla (amphibians, reptiles, aves and

247 mammals) (Figure 4B). Since sequence information from the Kunitz BPTI for fishes was

248 not available, we could not include those in the comparison. Out of these conserved

249 residues, $76 \%$ are conserved in venomous vertebrates (squamates and mammals) and

250 venomous invertebrates (scorpions and wasps) (Figure 4C) and $56 \%$ of the domain

251 residues are variable in at least one of two snake groups (viperids, and elapids) (Figure

252 4D). Of the residues that are evolved in the members of Crotalinae, the second residue,

253 a positively charged one, arginine $(R)$ is present only in the members of Viperinae, which 
254 is replaced by a hydrophobic residue, proline $(\mathrm{P})$, in the crotalines and elapids. Residues

255 14-18 are very polymorphic in the crotalines and elapids, but not so in the viperines.

256 The skin-derived putative CRISP gene homolog in Russell's viper is a 25kb long

257 gene, comprises of 8 exons coding for a $787 \mathrm{nt}$ transcript and two translated protein

258 domains, CAP and CRISP (Figure 5A). The CAP domain exhibits conservation in 7\% of

259 its residues across all the five vertebrate phyla (Figure 5B). Forty-two percent of those

260 residues are conserved across venomous vertebrates (amphibians, squamates and

261 mammals) and venomous invertebrates (scorpions and wasps) (Figure 5C). In addition,

262 there are five residues conserved across all the venomous animals (Figure 5C). Twenty-

263 seven percent of the CAP domain residues are variable in at least one of the three

264 snake groups (Figure 5D). There are several extra residues for the CAP domain in the

265 crotalines and elapids, but not in the viperines. The conserved residues comprised

266 mostly of Cystines and to a lesser extent Asparagines (Figure 5E) across venomous

267 vertebrates (squamates and mammals) (Figure 5F). Sixty percent of the residues in the

268 putative homolog of the CRISP domain are variable in at least one viperine or elapid

269 member with respect to the domain sequence of Russell's viper (Figure 5G).

270 Next, we explored the role of consensus domain sequences in the putative

271 protein homologs and the possible role of conserved amino acids in those domains

272 across viperids and elapids. We constructed the 3D structure models using Phyre2,

273 followed by Phyre2 investigation, for further analyses on the structural model. As evident

274 from the analyses, amino acid residues $18-19$ and 117 of the NGF domain reflected a

275 difference in mutation sensitivity as detected by SusPect algorithm (Yates et al. 2014),

276 especially in the elapids compared to the viperids (Figure 6). There were differences in

277 certain residues across these two groups. Residue 18 is Valine in the viperines and

278 Isoleucine in the elapids; residue 19 is Serine in the viperines and Asparagine in the 
279 crotalines; and residue 117 is Threonine in the elapids and Serine in the crotalines

280 (Figure 6A). This might have implications in the structure of the protein as the largest

281 pockets detected by fpocket algorithm appear to be vastly different among the

282 crotalines, viperines and elapids for the NGF, PDGF, CAP and CRISP domains (Figure

283 6). The pockets appeared smallest in all cases for the elapids (quantitatively substantial

284 for PDGF, CAP and CRISP: one-fourth that of viperines for PDGF, and two-thirds that of

285 viperines for CAP and CRISP), and largest in the case of viperines (Figure 6). Minor

286 differences in clashes were observed at residues 10,11 and 20 of the Kunitz domain and

287 residue 38 of this domain showed a rotamer conflict in the case of the crotalines (Figure

288 6C). Similarly, residue 46 of the CAP domain and residues 4 and 31 of the CRISP

289 domain showed rotamer conflict for the viperines (Figure 6D and Figure 6E). The other

290 protein quality and functional parameters were not affected across the 3D structure

291 models for the three snake groups (Fig. S8).

292 Discussion

293

Accessibility and affordability of high-throughput sequencing technologies along

294 with the availability of sophisticated computational tools to assemble, annotate and

295 interpret genomes is playing a powerful role in deciphering gene functions and their role

296 in evolution. Snake toxin genes are coded by gene families and produce gene isoforms

297 through the process of duplications (Casewell et al. 2013; Fry 2005). Several studies on

298 the venom-associated proteins from New World vipers have classified the venoms into

299 four groups (type I-IV), based on the relative abundance of toxin families (Calvete 2013;

300 Gibbs et al. 2013; Goncalves-Machado et al. 2016; Jimenez-Charris et al. 2015;

301 Lomonte et al. 2014; Mora-Obando et al. 2014; Pla et al. 2017; Salazar-Valenzuela et al.

302 2014). The different groups are: snake venom metalloproteinase-predominant (type I),

303 heterodimeric $\beta$-neurotoxic PLA2 -rich (type II), serine proteinases and PLA2 (type III) 
304 and type IV, which is similar to type III but with significant higher concentration of snake

305 venom metalloproteinases (Calvete 2017). Russell's viper (Daboia russelii) is a Old

306 World pitless viper, characterized by the lack of heat sensing pit organs (Mallow et al.

307 2003).

308 There is significant variation in the venom composition of Russell's viper in India

309 (Jayanthi \& Gowda 1988; Sharma et al. 2015), making the universal anti-venom less

310 effective against all Russell's viper bites across the country. The variation in the venom

311 composition within the same species is thought to be a result of adaptation in response

312 to the difference in diets (Barlow et al. 2009; Casewell et al. 2013; Daltry et al. 1996). A

313 comparison across four published studies (Kalita et al. 2017; Mukherjee et al. 2016;

314 Sharma et al. 2015; Tan et al. 2015) on Russell's viper venom proteins revealed that the

315 composition of some of the major venom proteins varied significantly (Figure S9). For

316 example, in one study (Mukherjee et al. 2016), VNGF constituted only $0.4 \%$ of the

317 venom while in another (Kalita et al. 2017), the same protein constituted $4.8 \%$ of the

318 venom. As both studies came from the same lab, there is little chance for any technical

319 or assay-related variability. In the first study, the venom was used from the captive

320 species in a zoo in the USA where the snake was from a Pakistani origin (Mukherjee et

321 al. 2016) while the other study used venom from a commercial source in India (Kalita et

322 al. 2017). This suggests that there is a great deal of variation in the composition of

323 Russell's viper venom collected from different locations, corroborating the earlier results

324 (Jayanthi \& Gowda 1988; Sharma et al. 2015). Currently, efforts are underway to collect

325 venoms of Russell's viper from different regions of India in order to understand their

326 composition (Rom Whitaker, and Gerry Martin, personal communications).

327 Studies on venom-associated genes using whole-genome sequencing data in

328 Russell's viper are scarce. One of the reasons is the relative difficulty in accessing 
329 venom glands from snakes. This can be partially addressed by studying their putative

330 homologs from shed skin, which is relatively easy to access. Past studies on the

331 members of Viperidae focused on proteins and used proteomics-based analyses (Gao

332 et al. 2013; Gao et al. 2014; Kalita et al. 2017; Li et al. 2004; Liu et al. 2011; Mukherjee

333 et al. 2016; Sharma et al. 2015; Tan et al. 2017; Tan et al. 2015; Villalta et al. 2012). The

334 only viperine where complete genome sequence information is available is a European

335 adder, Vipera berus berus (https://www.ncbi.nlm.nih.gov/bioproject/170536). Although

336 sequence information is available for this species, the annotation is not available and

337 therefore could not be used in our study.

338 The aim of the current study was two fold. First, as handling and getting biological

339 material from snakes requires specific expertise, we wanted to test whether one can

340 obtain high-molecular weight DNA from shed skin as a source of analyte for genome

341 sequencing. Second, we wanted to study the potential of skin-derived putative toxin

342 gene homologs, as surrogates of their venom gland counterparts through comparative

343 analyses. On the first account, we found the results to be satisfactory. Although shed

344 skin is often contaminated with bacteria and other microorganisms, and the DNA

345 obtained from the shed skin is sheared, we show that one can successfully isolate high-

346 molecular weight genomic DNA from shed skin (Fig. S1). Therefore, shed skin may be

347 an attractive option in the future for generating snake genome data. We showed that the

348 comparisons of amino acid sequence and three dimensional structures of five toxin

349 domains with their putative skin homologs across the major kingdoms of life can

350 generate important information towards understanding the macro- and micro-evolution

351 of these genes. Results from our comparative analyses showed that some of the venom

352 gland proteins are identical or near identical to their putative skin-derived homologs

353 (VNGF, 3FTX and LAAO) but others had low overall similarity (Snaclec and RVV). We 
354 were curious to find out whether the low sequence similarity for some venom proteins

355 with their putative homologs was specific to Russell's viper and how much of the low

356 overall similarity in those proteins was due to the heterogeneity, if any, found among

357 snakes of the same species. Comparative analysis between the toxins and their blood

358 homologs in king cobra provided us with an answer for the first question where 7 out of

3598 venom proteins studied (except for PLA2) were very similar to their blood homologs

360 (Fig. S4 and Fig. S5). This suggests that some venom proteins may not be that different

361 from their homologs in other organs. A recent study in python, where the authors argue

362 that the functional evidence of toxic effects on prey and not their expression is the

363 correct criterion to classify proteins as venom toxins (Reyes-Velasco et al. 2015),

364 strengthens this hypothesis further. However, we are aware that this may vary from

365 species to species and in some species the venom proteins may be very different from

366 their homologs in other organs.

367 In our study, we compared venom proteins described previously (Sharma et al.

368 2015) using animals captured near Chennai, Tamil Nadu, India with their skin-derived

369 putative homologs from a completely different animal (shed skin was collected in

370 Bangalore, Karnataka, India). The distance between these two places is roughly 350-

$371400 \mathrm{~km}$. Therefore; it is possible that in our study, the low similarity in some of the venom

372 proteins with their putative skin homologs could have been due to the variation in the

373 venom composition of the animals in these two locations. Despite this, $50 \%$ of the

374 venom proteins studied had $>75 \%$ and 3 had near perfect sequence similarity with their

375 putative skin homologs. A clear picture will emerge from a direct comparison between

376 the venom proteins and their skin counterparts from the same animal.

377 From the sequence data, we succeeded in assembling near complete CDS for 20

378 gene families representing 51 gene homologs (Fry 2005). This highlights the utility of 
379 genome sequencing data in inferring putative toxin gene homologs. As the lengths of the 380 putative toxin gene homologs in Russell's viper were much longer than the CDS, the 381 intronic sequences were assembled with gaps. This was primarily due to the low 382 coverage sequencing data used for assembly and the lack of long-insert mate pair 383 sequencing data in our repertoire. The aim of the current study was not to assemble a 384 perfect genome for Russell's viper but to use the low coverage data to fish out putative 385 toxin gene homologs from skin. The mean length of exons for the putative toxin gene 386 homologs in Russell's viper was 190 bases, much smaller compared to the average 387 intron length. In our study, we could assemble exons accurately using short-read 388 sequence data. Interestingly, we found that the AT to GC ratio in the CDS regions 389 (cumulatively for all the 51 toxin gene homologs) was 1:1 whereas it was skewed (the 390 ratio is $1.5: 1$ ) for the full gene sequences. Our study demonstrates the feasibility of de novo sequencing and analyses of 392 gene families without prior sequence information and annotation, and without going 393 through the process of designing individual primers for Sanger sequencing. However, 394 there are certain limitations to our study. First, it focuses on the putative toxin gene 395 homologs from skin and not the toxin genes from venom gland. There is a possibility that 396 the toxin genes from the same animal in the venom gland are different from their 397 homologs in the skin, and therefore can only be described as putative. Hence, we can 398 neither be sure of the presence nor the activity of the homologs in the skin. Although the 399 skin-derived transcriptome data will add value to the study, it will still be inadequate. 400 Future transcriptome and proteomics analysis from both the skin and the venom gland, 401 preferably from the same animal, along with their functional studies will only be 402 definitive. Second, like any other annotation-based study, we relied on the quality of 403 existing/prior annotation of toxin-related genes. It is possible that due to sequencing 
404 artefacts, there are errors in the assembled genomic sequence, and therefore in the

405 translated protein sequences inferred in our study. Future studies using high-coverage

406 sequencing data along with data on RNA and protein to derive better gene annotations

407 along with the functional studies on their spatial and temporal expression will point to the

408 true functional significance of skin-derived toxin gene homologs.

409 Acknowledgements

We thank Kunal Dhas and Arun Hariharan for their help in laboratory

411 experiments.

412

413

414

415

416

417

418

419

420

421

422

423

424

425

426

427

428

429

430

431

432

433

434

435

436

437

438

439

440

\section{Literature Cited}

Barlow A, Pook CE, Harrison RA, and Wuster W. 2009. Coevolution of diet and preyspecific venom activity supports the role of selection in snake venom evolution. Proc Biol Sci 276:2443-2449.

Calvete JJ. 2013. Snake venomics: from the inventory of toxins to biology. Toxicon 75:44-62.

Calvete JJ. 2017. Venomics: integrative venom proteomics and beyond. Biochem J 474:611-634.

Casewell NR, Wagstaff SC, Wuster W, Cook DA, Bolton FM, King SI, Pla D, Sanz L, Calvete JJ, and Harrison RA. 2014. Medically important differences in snake venom composition are dictated by distinct postgenomic mechanisms. Proc Natl Acad Sci U S A 111:9205-9210.

Casewell NR, Wuster W, Vonk FJ, Harrison RA, and Fry BG. 2013. Complex cocktails: the evolutionary novelty of venoms. Trends Ecol Evol 28:219-229.

Castoe TA, de Koning AP, Hall KT, Card DC, Schield DR, Fujita MK, Ruggiero RP, Degner JF, Daza JM, Gu W, Reyes-Velasco J, Shaney KJ, Castoe JM, Fox SE, Poole AW, Polanco D, Dobry J, Vandewege MW, Li Q, Schott RK, Kapusta A, Minx P, Feschotte C, Uetz P, Ray DA, Hoffmann FG, Bogden R, Smith EN, Chang BS, Vonk FJ, Casewell NR, Henkel CV, Richardson MK, Mackessy SP, Bronikowski AM, Yandell M, Warren WC, Secor SM, and Pollock DD. 2013. The Burmese python genome reveals the molecular basis for extreme adaptation in snakes. Proc Natl Acad Sci U S A 110:20645-20650.

Daltry JC, Wuster W, and Thorpe RS. 1996. Diet and snake venom evolution. Nature 379:537-540.

Dowell NL, Giorgianni MW, Kassner VA, Selegue JE, Sanchez EE, and Carroll SB. 2016. The Deep Origin and Recent Loss of Venom Toxin Genes in Rattlesnakes. Curr Biol 26:2434-2445.

Fetzner JW, Jr. 1999. Extracting high-quality DNA from shed reptile skins: a simplified method. Biotechniques 26:1052-1054. 
441 Finn RD, Coggill P, Eberhardt RY, Eddy SR, Mistry J, Mitchell AL, Potter SC, Punta M,

442

443

444

445

446

447

448

449

450

451

452

453

454

455

456

457

458

459

460

461

462

463

464

465

466

467

468

469

470

471

472

473

474

475

476

477

478

479

480

481

482

483

484

485

486

487

488
Qureshi M, Sangrador-Vegas A, Salazar GA, Tate J, and Bateman A. 2016. The

Pfam protein families database: towards a more sustainable future. Nucleic Acids Research 44:6.

Fry BG. 2005. From genome to "venome": molecular origin and evolution of the snake venom proteome inferred from phylogenetic analysis of toxin sequences and related body proteins. Genome Res 15:403-420.

Gao JF, Qu YF, Zhang XQ, He Y, and Ji X. 2013. Neonate-to-adult transition of snake venomics in the short-tailed pit viper, Gloydius brevicaudus. J Proteomics 84:148157.

Gao JF, Wang J, He Y, Qu YF, Lin LH, Ma XM, and Ji X. 2014. Proteomic and biochemical analyses of short-tailed pit viper (Gloydius brevicaudus) venom: agerelated variation and composition-activity correlation. J Proteomics 105:307-322.

Gelfman S, Burstein D, Penn O, Savchenko A, Amit M, Schwartz S, Pupko T, and Ast G. 2012. Changes in exon-intron structure during vertebrate evolution affect the splicing pattern of exons. Genome Res 22:35-50.

Gibbs HL, Sanz L, Sovic MG, and Calvete JJ. 2013. Phylogeny-based comparative analysis of venom proteome variation in a clade of rattlesnakes (Sistrurus sp.). PLoS One 8:e67220.

Goncalves-Machado L, Pla D, Sanz L, Jorge RJ, Leitao-De-Araujo M, Alves ML, Alvares DJ, De Miranda J, Nowatzki J, de Morais-Zani K, Fernandes W, Tanaka-Azevedo AM, Fernandez J, Zingali RB, Gutierrez JM, Correa-Netto C, and Calvete JJ. 2016. Combined venomics, venom gland transcriptomics, bioactivities, and antivenomics of two Bothrops jararaca populations from geographic isolated regions within the Brazilian Atlantic rainforest. J Proteomics 135:73-89.

Hargreaves AD, Swain MT, Hegarty MJ, Logan DW, and Mulley JF. 2014. Restriction and recruitment-gene duplication and the origin and evolution of snake venom toxins. Genome Biol Evol 6:2088-2095.

Hu B, Jin J, Guo AY, Zhang H, Luo J, and Gao G. 2015. GSDS 2.0: an upgraded gene feature visualization server. Bioinformatics 31:1296-1297.

Jayanthi GP, and Gowda TV. 1988. Geographical variation in India in the composition and lethal potency of Russell's viper (Vipera russelli) venom. Toxicon 26:257-264.

Jimenez-Charris E, Montealegre-Sanchez L, Solano-Redondo L, Mora-Obando D, Camacho E, Castro-Herrera F, Fierro-Perez L, and Lomonte B. 2015. Proteomic and functional analyses of the venom of Porthidium lansbergii lansbergii (Lansberg's hognose viper) from the Atlantic Department of Colombia. J Proteomics 114:287-299.

Kalita B, Patra A, and Mukherjee AK. 2017. Unraveling the Proteome Composition and Immuno-profiling of Western India Russell's Viper Venom for In-Depth Understanding of Its Pharmacological Properties, Clinical Manifestations, and Effective Antivenom Treatment. J Proteome Res 16:583-598.

Kelley LA, Mezulis S, Yates CM, Wass MN, and Sternberg MJ. 2015. The Phyre2 web portal for protein modeling, prediction and analysis. Nat Protoc 10:845-858.

Kerkkamp HM, Kini RM, Pospelov AS, Vonk FJ, Henkel CV, and Richardson MK. 2016. Snake Genome Sequencing: Results and Future Prospects. Toxins (Basel) 8.

Li S, Wang J, Zhang X, Ren Y, Wang N, Zhao K, Chen X, Zhao C, Li X, Shao J, Yin J, West MB, Xu N, and Liu S. 2004. Proteomic characterization of two snake venoms: Naja naja atra and Agkistrodon halys. Biochem J 384:119-127. 
489

490

491

492

493

494

495

496

497

498

499

500

501

502

503

504

505

506

507

508

509

510

511

512

513

514

515

516

517

518

519

520

521

522

523

524

525

526

527

528

529

530

531

532

533

534

535

536

537

Liu S, Yang F, Zhang Q, Sun MZ, Gao Y, and Shao S. 2011. "Anatomical" view of the protein composition and protein characteristics for Gloydius shedaoensis snake venom via proteomics approach. Anat Rec (Hoboken) 294:273-282.

Lomonte B, Fernandez J, Sanz L, Angulo Y, Sasa M, Gutierrez JM, and Calvete JJ. 2014. Venomous snakes of Costa Rica: biological and medical implications of their venom proteomic profiles analyzed through the strategy of snake venomics. J Proteomics 105:323-339.

Luo R, Liu B, Xie Y, Li Z, Huang W, Yuan J, He G, Chen Y, Pan Q, Liu Y, Tang J, Wu G, Zhang H, Shi Y, Liu Y, Yu C, Wang B, Lu Y, Han C, Cheung DW, Yiu SM, Peng S, Xiaogian Z, Liu G, Liao X, Li Y, Yang H, Wang J, Lam TW, and Wang J. 2012. SOAPdenovo2: an empirically improved memory-efficient short-read de novo assembler. Gigascience 1:18.

Malhotra A, Creer S, Harris JB, and Thorpe RS. 2015. The importance of being genomic: Non-coding and coding sequences suggest different models of toxin multi-gene family evolution. Toxicon 107:344-358.

Mallow D, Ludwig D, and Nilson G. 2003. True vipers : natural history and toxinology of Old World vipers. Malabar, Fla.: Krieger Pub. Co.

Mohapatra B, Warrell DA, Suraweera W, Bhatia P, Dhingra N, Jotkar RM, Rodriguez PS, Mishra K, Whitaker R, Jha P, and Million Death Study C. 2011. Snakebite mortality in India: a nationally representative mortality survey. PLoS Negl Trop Dis 5:e1018.

Mora-Obando D, Diaz C, Angulo Y, Gutierrez JM, and Lomonte B. 2014. Role of enzymatic activity in muscle damage and cytotoxicity induced by Bothrops asper Asp49 phospholipase A2 myotoxins: are there additional effector mechanisms involved? PeerJ 2:e569.

Mukherjee AK, Kalita B, and Mackessy SP. 2016. A proteomic analysis of Pakistan Daboia russelii russelii venom and assessment of potency of Indian polyvalent and monovalent antivenom. J Proteomics 144:73-86.

Pla D, Sanz L, Sasa M, Acevedo ME, Dwyer Q, Durban J, Perez A, Rodriguez Y, Lomonte B, and Calvete JJ. 2017. Proteomic analysis of venom variability and ontogeny across the arboreal palm-pitvipers (genus Bothriechis). J Proteomics 152:1-12.

Reyes-Velasco J, Card DC, Andrew AL, Shaney KL, Adams RH, Schield DR, Casewell NR, Mackessy SP, Castoe TA. 2015. Expression of Venom Gene Homologs in Diverse Python Tissues Suggests a New Model for the Evolution of Snake Venom. Mol Biol Evol 32:173-183.

Rokyta DR, Wray KP, Lemmon AR, Lemmon EM, and Caudle SB. 2011. A highthroughput venom-gland transcriptome for the Eastern Diamondback Rattlesnake (Crotalus adamanteus) and evidence for pervasive positive selection across toxin classes. Toxicon 57:657-671.

Salazar-Valenzuela D, Mora-Obando D, Fernandez ML, Loaiza-Lange A, Gibbs HL, and Lomonte B. 2014. Proteomic and toxicological profiling of the venom of Bothrocophias campbelli, a pitviper species from Ecuador and Colombia. Toxicon 90:15-25.

Schmieder R, and Edwards R. 2011. Fast identification and removal of sequence contamination from genomic and metagenomic datasets. PLoS One 6:e17288.

Sharma M, Das D, lyer JK, Kini RM, and Doley R. 2015. Unveiling the complexities of Daboia russelii venom, a medically important snake of India, by tandem mass spectrometry. Toxicon 107:266-281. 
538

539

540

541

542

543

544

545

546

547

548

549

550

551

552

553

554

555

556

557

558

559

560

561

562

563

564

565

566

567

568

569

570

571

572

573

574

575

576

577

Tan CH, Tan KY, Yap MK, and Tan NH. 2017. Venomics of Tropidolaemus wagleri, the sexually dimorphic temple pit viper: Unveiling a deeply conserved atypical toxin arsenal. Sci Rep 7:43237.

Tan NH, Fung SY, Tan KY, Yap MK, Gnanathasan CA, and Tan CH. 2015. Functional venomics of the Sri Lankan Russell's viper (Daboia russelii) and its toxinological correlations. J Proteomics 128:403-423.

Ullate-Agote A, Milinkovitch MC, and Tzika AC. 2014. The genome sequence of the corn snake (Pantherophis guttatus), a valuable resource for EvoDevo studies in squamates. Int J Dev Biol 58:881-888.

Vicoso B, Emerson JJ, Zektser Y, Mahajan S, and Bachtrog D. 2013. Comparative sex chromosome genomics in snakes: differentiation, evolutionary strata, and lack of global dosage compensation. PLoS Biol 11:e1001643.

Villalta M, Pla D, Yang SL, Sanz L, Segura A, Vargas M, Chen PY, Herrera M, Estrada $\mathrm{R}$, Cheng YF, Lee CD, Cerdas M, Chiang JR, Angulo Y, Leon G, Calvete JJ, and Gutierrez JM. 2012. Snake venomics and antivenomics of Protobothrops mucrosquamatus and Viridovipera stejnegeri from Taiwan: keys to understand the variable immune response in horses. J Proteomics 75:5628-5645.

Vonk FJ, Casewell NR, Henkel CV, Heimberg AM, Jansen HJ, McCleary RJ, Kerkkamp HM, Vos RA, Guerreiro I, Calvete JJ, Wuster W, Woods AE, Logan JM, Harrison RA, Castoe TA, de Koning AP, Pollock DD, Yandell M, Calderon D, Renjifo C, Currier RB, Salgado D, Pla D, Sanz L, Hyder AS, Ribeiro JM, Arntzen JW, van den Thillart GE, Boetzer M, Pirovano W, Dirks RP, Spaink HP, Duboule D, McGlinn E, Kini RM, and Richardson MK. 2013. The king cobra genome reveals dynamic gene evolution and adaptation in the snake venom system. Proc Natl Acad Sci U S A 110:20651-20656.

Vonk FJ, Jackson K, Doley R, Madaras F, Mirtschin PJ, and Vidal N. 2011. Snake venom: From fieldwork to the clinic: Recent insights into snake biology, together with new technology allowing high-throughput screening of venom, bring new hope for drug discovery. Bioessays 33:269-279.

Warrell DA, Gutierrez JM, Calvete JJ, and Williams D. 2013. New approaches \& technologies of venomics to meet the challenge of human envenoming by snakebites in India. Indian J Med Res 138:38-59.

Whitaker R. 2015. Snakebite in India today. Neurol India 63:300-303.

Yates CM, Filippis I, Kelley LA, and Sternberg MJ. 2014. SuSPect: enhanced prediction of single amino acid variant (SAV) phenotype using network features. $J$ Mol Biol 426:2692-2701.

Yin W, Wang ZJ, Li QY, Lian JM, Zhou Y, Lu BZ, Jin LJ, Qiu PX, Zhang P, Zhu WB, Wen B, Huang YJ, Lin ZL, Qiu BT, Su XW, Yang HM, Zhang GJ, Yan GM, and Zhou Q. 2016. Evolutionary trajectories of snake genes and genomes revealed by comparative analyses of five-pacer viper. Nat Commun 7:13107. 


\section{Figure Legends}

579 Figure 1: Sequence identity (\%) between the proteins from ten major venom families

580 and their putative skin homologs in Russell's viper. The homolog with the highest identity

581 was considered where more than one homolog was present.

582 Figure 2: Comparative analyses of nerve growth factor (NGF). Putative NGF gene 583 homolog, its mRNA, and protein domains in Russell's viper (A) and its comparison with

584 the consensus NGF sequences from all five vertebrate phyla (fishes, amphibians, 585 reptiles, birds and mammals) (B), with venomous $(\mathrm{V})$ vertebrates from multiple phyla of 586 vertebrates and invertebrates (C), and from various reptilian subgroups (D) are shown.

587 The shades of brown and grey in B and $\mathrm{C}$ represent conservation to various degrees

588 and variability, respectively. Grey in D represents conserved residues, red represents

589 variable residues in the crotalines $(C R)$, yellow and green represent conserved and

590 variable residues in the viperines (VP), and elapids respectively.

591 Figure 3: Comparative analyses of vascular endothelial growth factor - A (VEGF-A).

592 Organization of the putative gene homolog, its mRNA, and protein domains of Russell's 593 viper PDGF domain (A) and its comparison with the consensus sequences from all five 594 vertebrate phyla (fishes, amphibians, reptiles, birds and mammals) (B), from the 595 venomous $(\mathrm{V})$ vertebrates and invertebrates $(\mathrm{C})$, and from various reptilian subgroups

596 (D) are shown. The shades of brown and grey in B and C represent conserved and 597 varying residues, respectively. Grey in D represents conserved residues, red represents 598 variable residues in the crotalines (CR), yellow and green represent conserved and 599 variable residues in viperines (VP), and elapids respectively.

600 Figure 4: Comparative analyses of kunitoxin. Organization of the putative gene 601 homolog, its mRNA, and protein domains of Russell's viper (A) and its comparison with 602 the consensus BPTI domain sequences from all five vertebrate phyla (fishes, 
603 amphibians, reptiles, birds and mammals) (B), from venomous (V) vertebrates and 604 invertebrates (C), from various reptilian subgroups (D) are shown. The shades of brown 605 and grey in B and C represent conserved and varying residues, respectively. Grey in D 606 represents conserved residues, red represents variable residues in the crotalines (CR), 607 yellow and green represent conserved and variable residues in viperines (VP), and 608 elapids respectively.

609 Figure 5: Comparative analyses of CRISP. Organization of putative CRISP gene 610 homolog, its mRNA, and protein domains of Russell's viper (A) and its comparison with 611 the consensus CRISP sequences from all five vertebrate phyla (fishes, amphibians, 612 reptiles, birds and mammals, B and E); from venomous animals (V) vertebrates (fishes, 613 squamates and mammals) and invertebrates (scorpions and wasps, C and F); and from 614 various reptilian subgroups ( $D$ and $G$ ) are shown. The shades of brown and grey in $B, C$,

615 E and $F$ represent conserved and varying residues, respectively. Grey in D and G 616 represents conserved residues, red represents variable residues in the crotalines (CR), 617 yellow and green represent conserved and variable residues in viperines (VP), and 618 elapids respectively.

619 Figure 6: Three-dimensional protein structural models in NGF (A); PDGF (B); Kunitz 620 BPTI (C); CAP (D); and CRISP (E) across crotalines (CR), viperines (VP) and elapids. 621 The status of the parameters being investigated using Phyre2 are indicated in the color 622 legends on the side. 


\section{Table $\mathbf{1}$ (on next page)}

Genes and their representative families used in the current study.

The homolog with the highest identity was considered in cases with more than one homolog. 


\begin{tabular}{|c|c|c|}
\hline Gene & $\begin{array}{l}\text { Species with the available sequence } \\
\text { information }\end{array}$ & Protein Family \\
\hline$A C H E$ & \multirow{5}{*}{$\begin{array}{l}\text { Protobothrops mucrosquamatus, } \\
\text { Ophiophagus hannah, Python bivittatus } \\
\text { and Thamnophis sirtalis }\end{array}$} & Acetylcholinesterase \\
\hline ADAM11 & & \multirow{4}{*}{$\begin{array}{l}\text { ADAM (disintegrin/ } \\
\text { metalloprotease) }\end{array}$} \\
\hline ADAM17 & & \\
\hline ADAM19 & & \\
\hline ADAM23 & & \\
\hline PROK1 & $\begin{array}{l}\text { Protobothrops mucrosquamatus, } \\
\text { Ophiophagus hannah and Python } \\
\text { bivitattus }\end{array}$ & \multirow{2}{*}{ AVIT (prokinectin) } \\
\hline PROK2 & $\begin{array}{l}\text { Protobothrops mucrosquamatus and } \\
\text { Ophiophagus hannah, Python bivittatus } \\
\text { and Thamnophis sirtalis }\end{array}$ & \\
\hline CPAMD8 & $\begin{array}{l}\text { Protobothrops mucrosquamatus, Python } \\
\text { bivittatus and Thamnophis sirtalis }\end{array}$ & Complement C3 \\
\hline crotasin & Protobothrops mucrosquamatus & $\begin{array}{l}\text { Crotasin/ } \\
\text { beta defensin }\end{array}$ \\
\hline CST1 & $\begin{array}{l}\text { No sequence information is available in } \\
\text { any of the four species }\end{array}$ & \multirow{4}{*}{ Cystatin } \\
\hline CST3 & Ophiophagus hannah & \\
\hline CST4 & $\begin{array}{l}\text { No sequence information is available in } \\
\text { any of the four species }\end{array}$ & \\
\hline CSTA & $\begin{array}{l}\text { Protobothrops mucrosquamatus and } \\
\text { Thamnophis sirtalis }\end{array}$ & \\
\hline EDN1 & $\begin{array}{l}\text { Protobothrops mucrosquamatus and } \\
\text { Python bivittatus }\end{array}$ & \multirow[t]{2}{*}{ Endothelin } \\
\hline EDN3 & \multirow{2}{*}{$\begin{array}{l}\text { Protobothrops mucrosquamatus, } \\
\text { Ophiophagus hannah, Python bivittatus, } \\
\text { Thamnophis sirtalis and }\end{array}$} & \\
\hline F5 & & Factor V \\
\hline F10 & Ophiophagus hannah & Factor $\mathrm{X}$ \\
\hline KLKB1 & $\begin{array}{l}\text { Protobothrops mucrosquamatus, } \\
\text { Ophiophagus hannah, Python bivittatus, } \\
\text { Thamnophis sirtalis and }\end{array}$ & \multirow[t]{2}{*}{ Kallikrein } \\
\hline KLK14 & Ophiophagus hannah & \\
\hline kunitoxin & $\begin{array}{l}\text { Protobothrops mucrosquamatus, Python } \\
\text { bivittatus and Ophiophagus hannah }\end{array}$ & $\begin{array}{l}\text { Kunitz-type protease } \\
\text { inhibitor }\end{array}$ \\
\hline LYNX1 & Ophiophagus hannah & LYNX/SLUR \\
\hline CLEC3A & $\begin{array}{l}\text { Protobothrops mucrosquamatus, Python } \\
\text { bivittatus and Thamnophis sirtalis }\end{array}$ & \multirow{4}{*}{ Lectin } \\
\hline CLEC3B & $\begin{array}{l}\text { Protobothrops mucrosquamatus, } \\
\text { Ophiophagus hannah, Python bivittatus } \\
\text { and Thamnophis sirtalis }\end{array}$ & \\
\hline CLEC11A & $\begin{array}{l}\text { Protobothrops mucrosquamatus, Python } \\
\text { bivittatus and Thamnophis sirtalis }\end{array}$ & \\
\hline CLEC16A & $\begin{array}{l}\text { Protobothrops mucrosquamatus, Python } \\
\text { bivittatus and Thamnophis sirtalis }\end{array}$ & \\
\hline
\end{tabular}




\begin{tabular}{|c|c|c|}
\hline CLEC19A & $\begin{array}{l}\text { Protobothrops mucrosquamatus and } \\
\text { Python bivittatus }\end{array}$ & \\
\hline NPR1 & $\begin{array}{l}\text { Protobothrops mucrosquamatus, Python } \\
\text { bivittatus and Thamnophis sirtalis }\end{array}$ & \multirow{3}{*}{ Natriuretic peptide } \\
\hline NPR2 & \multirow{2}{*}{$\begin{array}{l}\text { Protobothrops mucrosquamatus, } \\
\text { Ophiophagus hannah, Python bivittatus } \\
\text { and Thamnophis sirtalis }\end{array}$} & \\
\hline NPR3 & & \\
\hline$N G F$ & $\begin{array}{l}\text { Protobothrops mucrosquamatus, } \\
\text { Ophiophagus hannah, Python bivittatus, } \\
\text { Thamnophis sirtalis, Protobothrops } \\
\text { flavoviridis, Crotalus horridus, Sistrurus } \\
\text { miliarius barbouri and Boa constrictor }\end{array}$ & $\begin{array}{l}\text { Beta-nerve growth } \\
\text { factor }\end{array}$ \\
\hline$P L A A$ & \multirow{2}{*}{$\begin{array}{l}\text { Protobothrops mucrosquamatus, } \\
\text { Ophiophagus hannah, Python bivittatus } \\
\text { and Thamnophis sirtalis }\end{array}$} & \multirow{12}{*}{ Phospholipase A (2) } \\
\hline PLA2R1 & & \\
\hline PLA2G1B & $\begin{array}{l}\text { Python bivittatus, Thamnophis sirtalis and } \\
\text { Protobothrops mucrosquamatus }\end{array}$ & \\
\hline PLA2G10 & $\begin{array}{l}\text { Protobothrops mucrosquamatus, } \\
\text { Protobothrops flavoviridis, Thamnophis } \\
\text { sirtalis, Ophiophagus hanna and Python } \\
\text { bivittatus }\end{array}$ & \\
\hline PLA2G12A & $\begin{array}{l}\text { Python bivittatus, Thamnophis sirtalis and } \\
\text { Protobothrops mucrosquamatus }\end{array}$ & \\
\hline PLA2G12B & $\begin{array}{l}\text { Protobothrops mucrosquamatus, } \\
\text { Ophiophagus hannah and Python } \\
\text { bivittatus }\end{array}$ & \\
\hline PLA2G15 & $\begin{array}{l}\text { Protobothrops mucrosquamatus, } \\
\text { Ophiophagus hannah, Python bivittatus } \\
\text { and Thamnophis sirtalis }\end{array}$ & \\
\hline PLA2G3 & $\begin{array}{l}\text { Protobothrops mucrosquamatus, Python } \\
\text { bivittatus and Ophiophagus hannah }\end{array}$ & \\
\hline PLA2G4A & $\begin{array}{l}\text { Protobothrops mucrosquamatus, } \\
\text { Ophiophagus hannah, Python bivittatus } \\
\text { and Thamnophis sirtalis }\end{array}$ & \\
\hline PLA2G4C & $\begin{array}{l}\text { Protobothrops mucrosquamatus, Python } \\
\text { bivittatus and Thamnophis sirtalis }\end{array}$ & \\
\hline PLA2G6 & \multirow{2}{*}{$\begin{array}{l}\text { Protobothrops mucrosquamatus, } \\
\text { Ophiophagus hannah, Python bivittatus } \\
\text { and Thamnophis sirtalis }\end{array}$} & \\
\hline PLA2G7 & & \\
\hline SPSB4 & $\begin{array}{l}\text { Protobothrops mucrosquamatus and } \\
\text { Thamnophis sirtalis }\end{array}$ & \multirow{3}{*}{ SPla/Ryanodine } \\
\hline SPSB3 & $\begin{array}{l}\text { Protobothrops mucrosquamatus, Python } \\
\text { bivittatus and Thamnophis sirtalis }\end{array}$ & \\
\hline SPSB1 & $\begin{array}{l}\text { Protobothrops mucrosquamatus, } \\
\text { Ophiophagus hannah, Python bivittatus } \\
\text { and Thamnophis sirtalis }\end{array}$ & \\
\hline
\end{tabular}




\begin{tabular}{|c|c|c|}
\hline VEGFA1 & \multirow{3}{*}{$\begin{array}{l}\text { Protobothrops mucrosquamatus, } \\
\text { Ophiophagus hannah, Python bivittatus, } \\
\text { Thamnophis sirtalis, Crotalus horridus } \\
\text { and Protobothrops flavoviridis }\end{array}$} & \multirow{6}{*}{$\begin{array}{l}\text { Vascular endothelial } \\
\text { growth factor } \\
\text { (VEGF) }\end{array}$} \\
\hline VEGFA2 & & \\
\hline VEGFA3 & & \\
\hline VEGFB & $\begin{array}{l}\text { Protobothrops mucrosquamatus, } \\
\text { Ophiophagus hannah, Python bivittatus, } \\
\text { Thamnophis sirtalis, Crotalus horridus, } \\
\text { Protobothrops flavoviridis and Sistrurus } \\
\text { miliarius barbouri }\end{array}$ & \\
\hline VEGFC & $\begin{array}{l}\text { Protobothrops mucrosquamatus, Python } \\
\text { bivittatus and Thamnophis sirtalis }\end{array}$ & \\
\hline VEGFF & $\begin{array}{l}\text { Protobothrops mucrosquamatus, } \\
\text { Ophiophagus hannah, Python bivittatus, } \\
\text { Thamnophis sirtalis and Protobothrops } \\
\text { flavoviridis }\end{array}$ & \\
\hline WAP & \multirow{3}{*}{$\begin{array}{l}\text { Protobothrops mucrosquamatus, Python } \\
\text { bivittatus, Thamnophis sirtalis and } \\
\text { Ophiophagus hannah }\end{array}$} & \multirow{3}{*}{$\begin{array}{l}\text { Whey acidic } \\
\text { protein/secretory } \\
\text { leukoproteinase } \\
\text { inhibitor }\end{array}$} \\
\hline WFIKKN1 & & \\
\hline WFIKKN2 & & \\
\hline CRISP & $\begin{array}{l}\text { Protobothrops flavoviridis, Protobothrops } \\
\text { mucrosquamatus, Ophiophagus hannah, } \\
\text { Python bivittatus, Thamnophis sirtalis, } \\
\text { Crotalus horridus, Calloselasma } \\
\text { rhodostoma, Sistrurus miliarius barbouri } \\
\text { and Deinagkistrodon acutus }\end{array}$ & CRISP \\
\hline
\end{tabular}




\section{Figure 1 (on next page)}

Sequence identity (\%) between the proteins from ten major venom families and their putative skin homologs in Russell's viper.

The homolog with the highest identity was considered where more than one homolog was present. 


\section{Figure 2}

Comparative analyses of nerve growth factor (NGF).

Putative NGF gene homolog, its mRNA, and protein domains in Russell's viper (A) and its comparison with the consensus NGF sequences from all five vertebrate phyla (fishes, amphibians, reptiles, birds and mammals) (B), with venomous (V) vertebrates from multiple phyla of vertebrates and invertebrates (C), and from various reptilian subgroups (D) are shown. The shades of brown and grey in $B$ and $C$ represent conservation to various degrees and variability, respectively. Grey in D represents conserved residues, red represents variable residues in the crotalines (CR), yellow and green represent conserved and variable residues in the viperines (VP), and elapids respectively. 


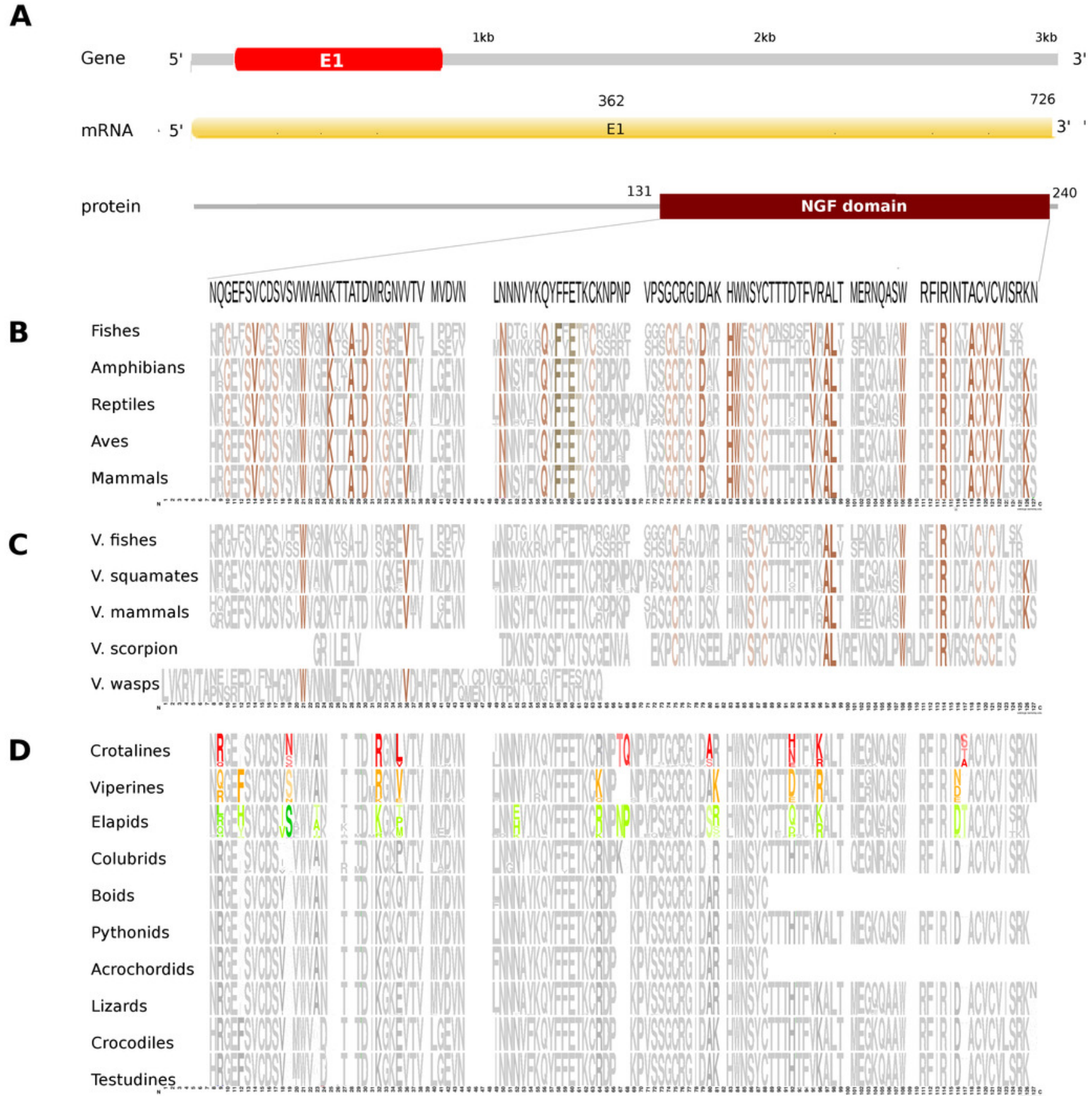




\section{Figure 3}

Comparative analyses of vascular endothelial growth factor - A (VEGF-A).

Organization of the putative gene homolog, its mRNA, and protein domains of Russell's viper PDGF domain ( $A$ ) and its comparison with the consensus sequences from all five vertebrate phyla (fishes, amphibians, reptiles, birds and mammals) (B), from the venomous (V) vertebrates and invertebrates (C), and from various reptilian subgroups (D) are shown. The shades of brown and grey in $B$ and $C$ represent conserved and varying residues, respectively. Grey in $D$ represents conserved residues, red represents variable residues in the crotalines (CR), yellow and green represent conserved and variable residues in viperines (VP), and elapids respectively. 
A

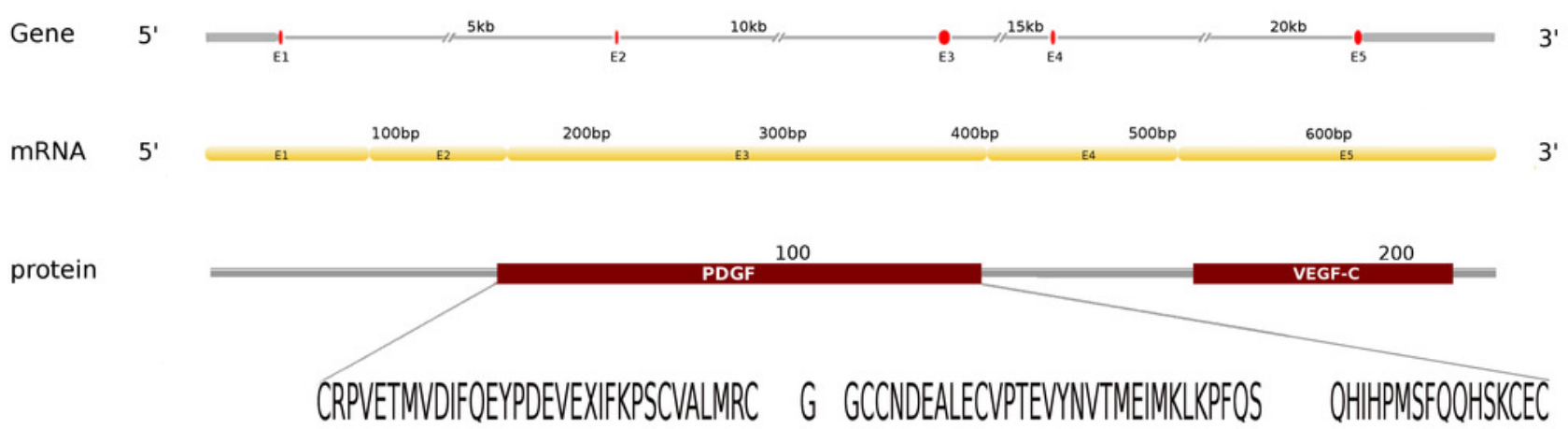

B

C

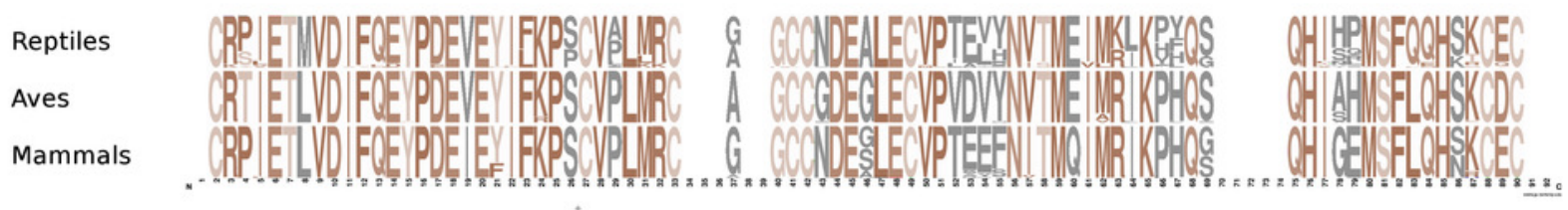

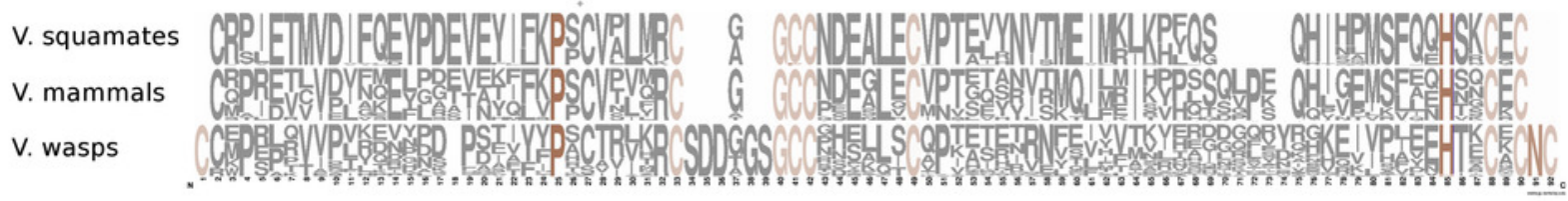

D

\begin{tabular}{|c|c|c|}
\hline NWV & Cap $E$ & $\mathbb{A R C}$ \\
\hline owv & 71 & $x p$ \\
\hline Elapids & & \\
\hline Colubrids & $E \mid P D$ & \\
\hline Pythonids & $F E(P)=$ & \\
\hline Lizards & OCEPDE & IJUYI \\
\hline Crocodiles & Unl & 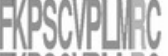 \\
\hline estudines & clpoze & \\
\hline
\end{tabular}
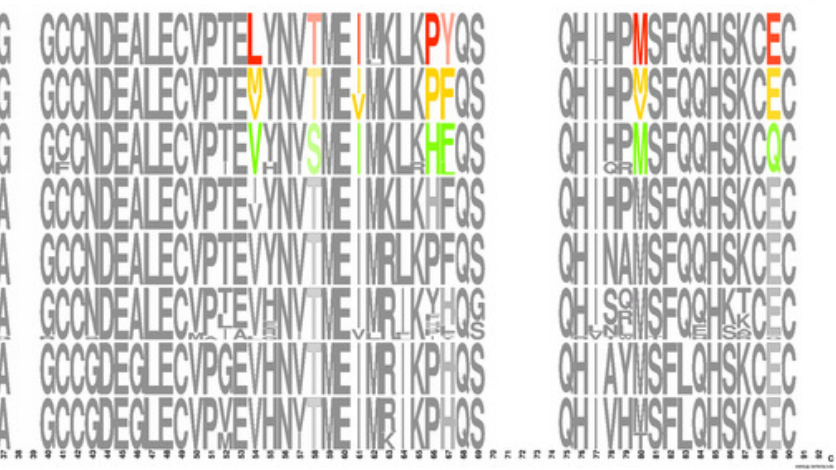


\section{Figure 4}

Comparative analyses of kunitoxin.

Organization of the putative gene homolog, its mRNA, and protein domains of Russell's viper (A) and its comparison with the consensus BPTI domain sequences from all five vertebrate phyla (fishes, amphibians, reptiles, birds and mammals) (B), from venomous (V) vertebrates and invertebrates (C), from various reptilian subgroups (D) are shown. The shades of brown and grey in $B$ and $C$ represent conserved and varying residues, respectively. Grey in D represents conserved residues, red represents variable residues in the crotalines (CR), yellow and green represent conserved and variable residues in viperines (VP), and elapids respectively. 
A

Gene

$5^{\prime}$

$1 \mathrm{~kb}$

$2 \mathrm{~kb}$

$3 \mathrm{~kb}$

$3^{\prime}$

mRNA

$5^{\prime}$

100

200

protein

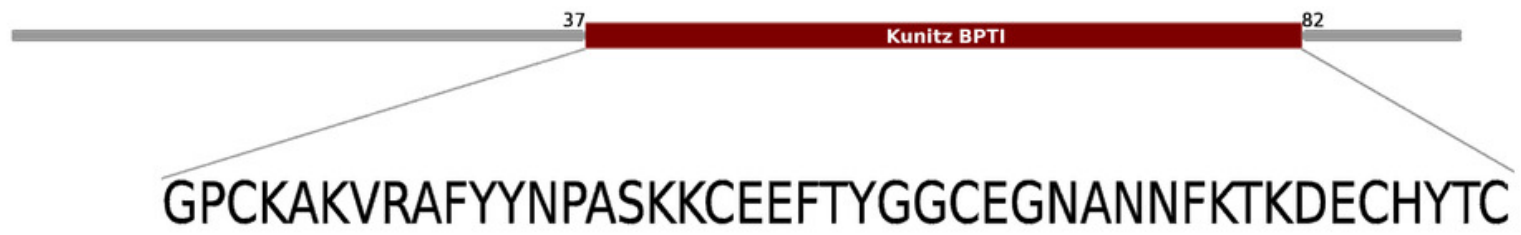

B

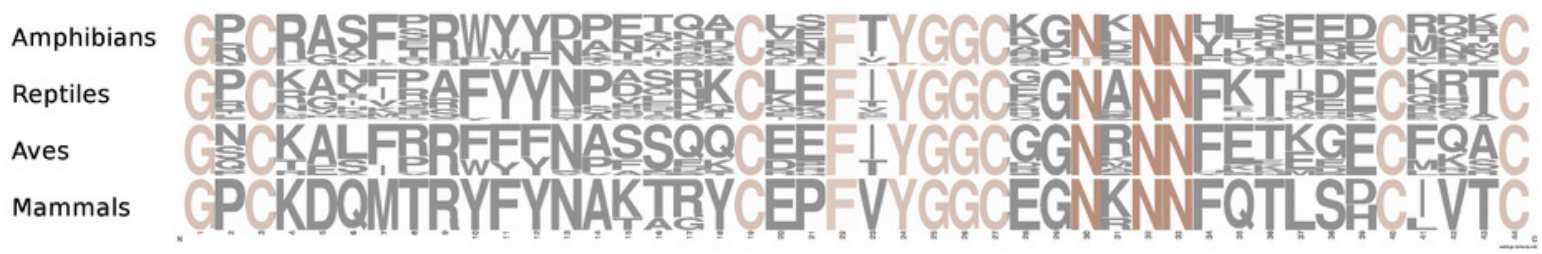

C

V. squamates

V. mammals

V. scorpion

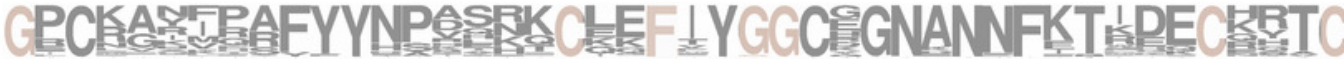

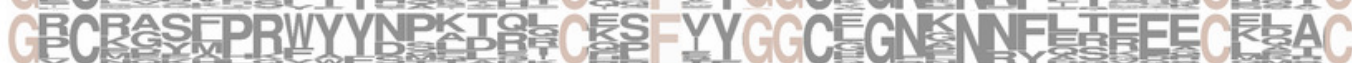

V. wasps

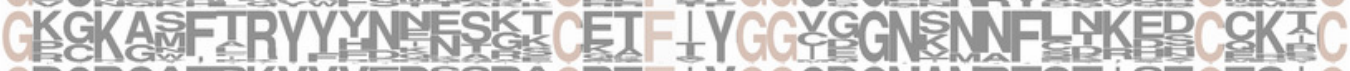

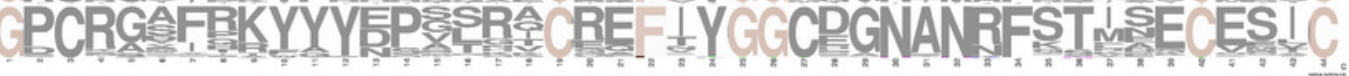

D

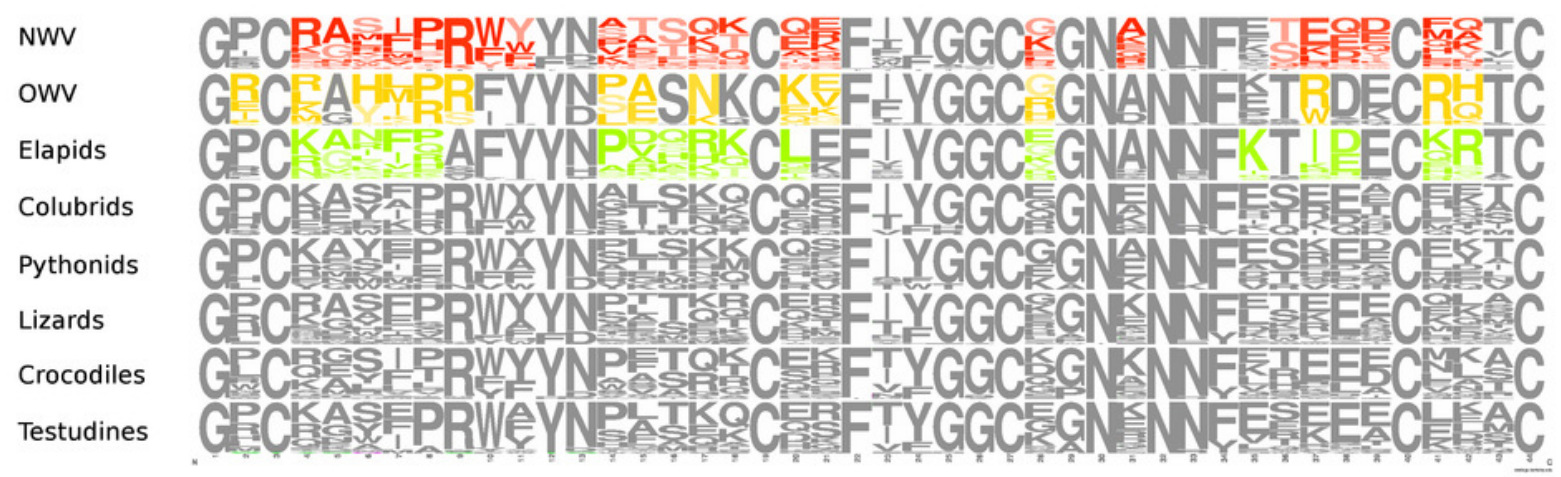




\section{Figure 5}

Comparative analyses of CRISP.

Organization of putative CRISP gene homolog, its mRNA, and protein domains of Russell's viper $(A)$ and its comparison with the consensus CRISP sequences from all five vertebrate phyla (fishes, amphibians, reptiles, birds and mammals, $B$ and $E$ ); from venomous animals (V) vertebrates (fishes, squamates and mammals) and invertebrates (scorpions and wasps, C and F); and from various reptilian subgroups ( $D$ and $G$ ) are shown. The shades of brown and grey in B, C, E and F represent conserved and varying residues, respectively. Grey in D and G represents conserved residues, red represents variable residues in the crotalines (CR), yellow and green represent conserved and variable residues in viperines (VP), and elapids respectively.

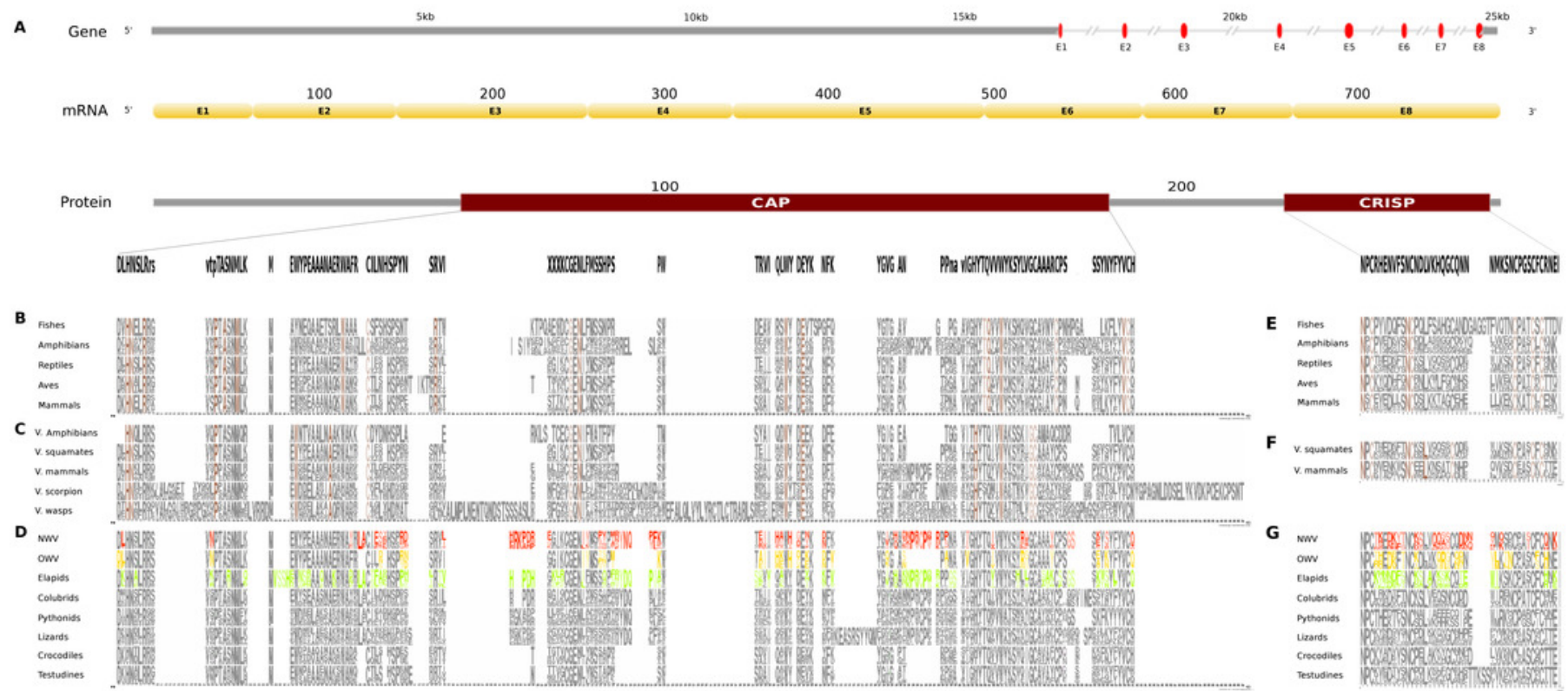




\section{Figure 6}

Three dimensional protein structural models in NGF (A); PDGF (B); Kunitz BPTI (C); CAP (D); and CRISP (E) across crotalines (CR), viperines (VP) and elapids.

The status of the parameters being investigated using Phyre2 are indicated in the color legends on the side. 
A

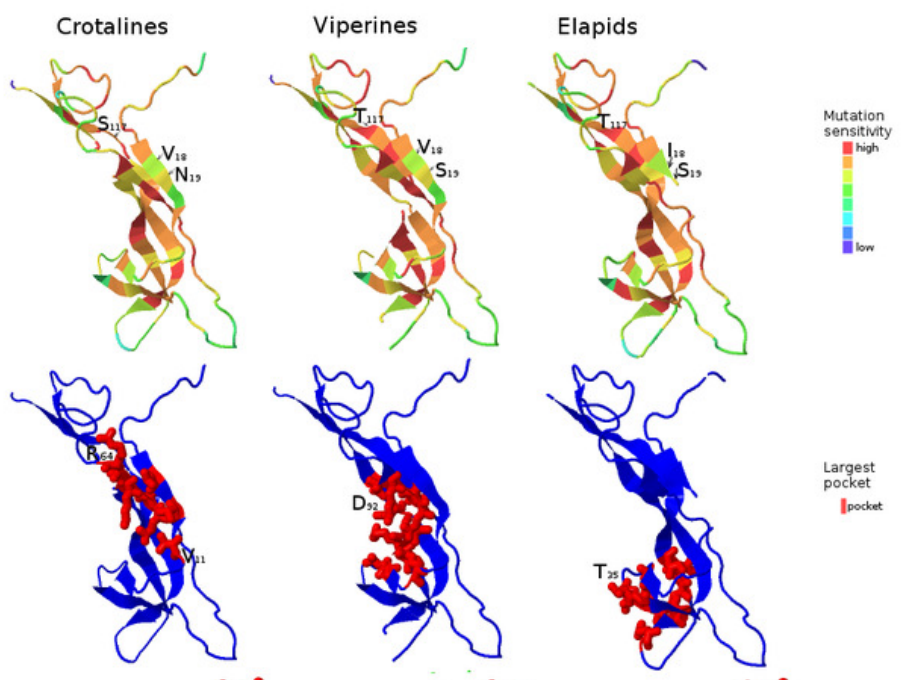

B

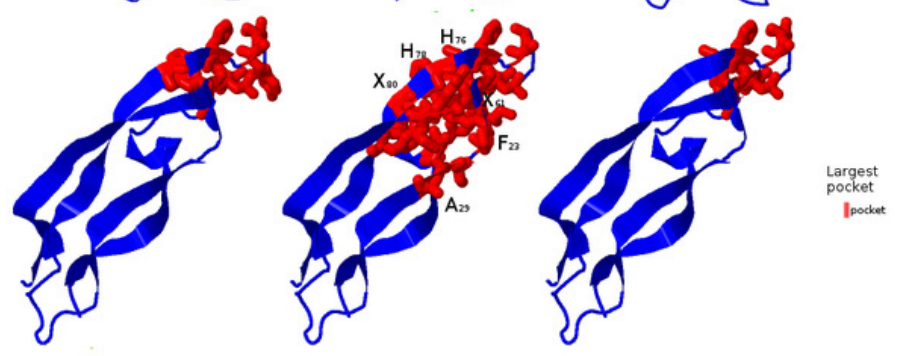

C

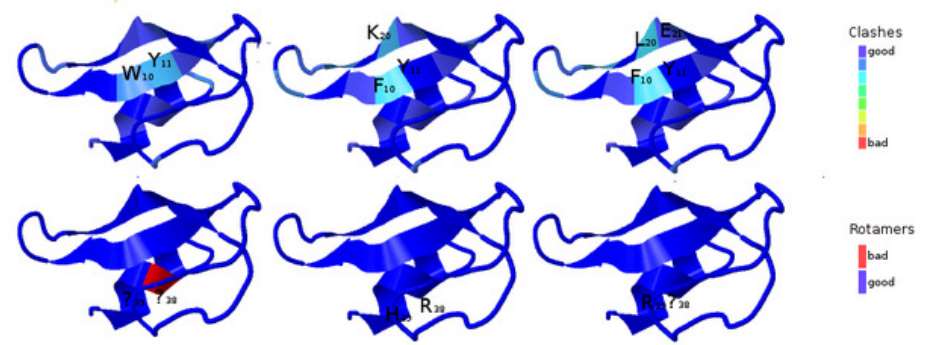

D
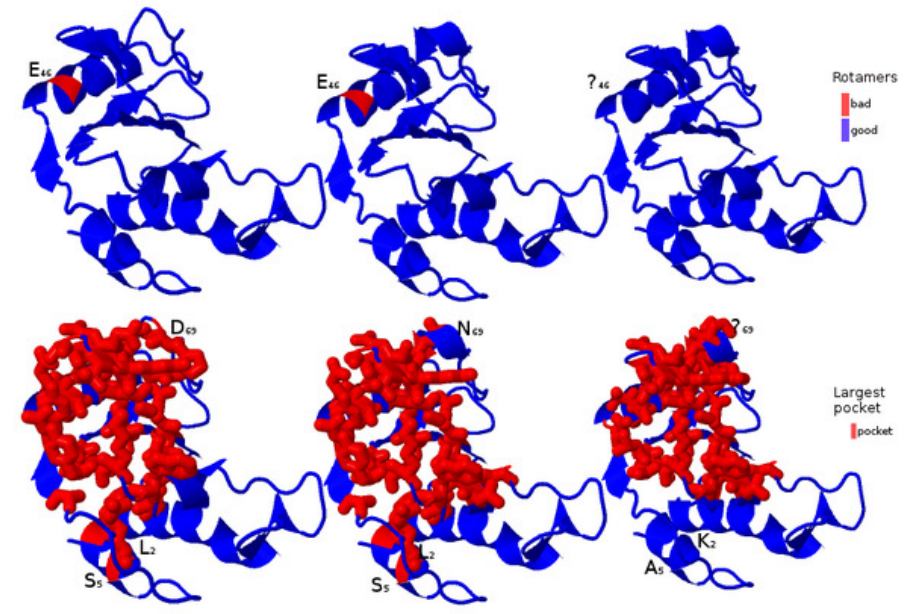

E
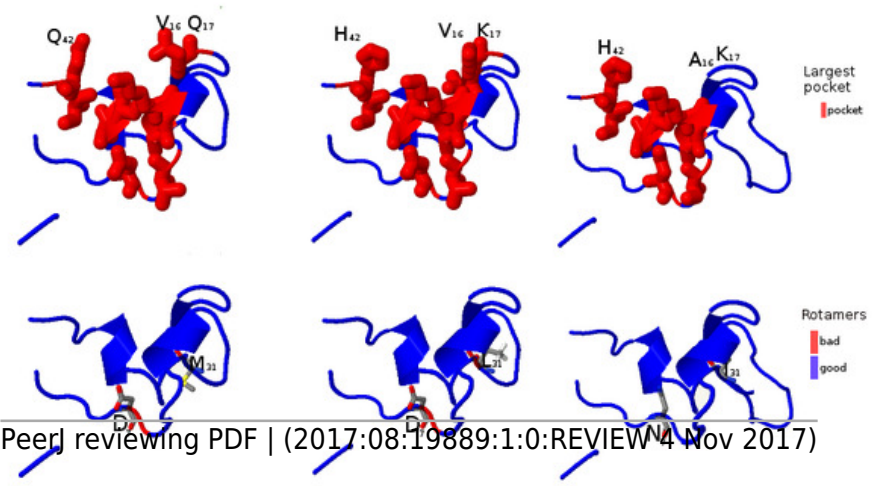